\title{
CHARACTERIZATION AND EFFECTIVENESS OF MORINGA OLEIFERA SEEDS EXTRACT AS A PHOSPHATE COAGULANT
}

\author{
Nishfu Sya'banah, Eny Yulianti*, Vina Nurul Istighfarini, Fadilah Nor Laili Lutfia \\ Department of Chemistry, Universitas Islam Negeri Maulana Malik Ibrahim Malang, \\ Jl. Gajayana 50 Malang, Indonesia
}

Received: $23^{\text {rd }}$ December 2019; Revised: $17^{\text {th }}$ February 2020; Accepted: $7^{\text {th }}$ April 2020

\begin{abstract}
In this research, Moringa oleifera seeds extract has been shown the ability as a coagulation agent. The molecules that act as the coagulation agents were the proteins which were obtained by the extraction process of the Moringa seeds using $\mathrm{NaCl}$ solution. The aim of this research was to characterize and test the effectiveness of the Moringa seeds extract as a phosphate coagulant. The determination of the coagulation process was carried out using a Jar Test method of phosphate solution samples, and then effectiveness the samples were analyzed using a UV-Vis spectroscopy after-treatment of the coagulant dose variations, depositional time, and the $\mathrm{pH}$ variations of the samples. The characterization of the extract functional groups was determined using an FTIR spectroscopy. The results of the coagulation phosphate sample examinations showed that the optimum dose of the coagulant was $80 \mathrm{~mL} / \mathrm{L}$, with a decrease in the initial phosphate concentration of $17 \mathrm{ppm}$ to $13.58 \mathrm{ppm}$. The reduction effect of precipitation time and $\mathrm{pH}$ also was obtained in this research. The optimum precipitation time and $\mathrm{pH}$ were in 30 minutes and $\mathrm{pH} \mathrm{8,} \mathrm{which} \mathrm{reduced} \mathrm{the} \mathrm{phosphate} \mathrm{concentration} \mathrm{to} 11.697$ and $9.6 \mathrm{ppm}$, respectively. The FTIR spectra of Moringa oleifera seeds extracts before and after interacting with phosphate showed their differences. The interactions between the extract and phosphate were demonstrated by the appearance of buckling vibrations at wavenumbers $1064.2 \mathrm{~cm}^{-1}, 799.8 \mathrm{~cm}^{-1}$, and $668.8 \mathrm{~cm}^{-1}$. The results of this study indicated that the Moringa seeds extraction with $\mathrm{NaCl}$ has potential as a phosphate coagulation agent.
\end{abstract}

Keywords: Coagulant; Dosage; Moringa Seeds; Deposition Time; pH; Phosphate

\section{Introduction}

Excessive nutrition in the environment can causes problems for the environment itself. Phosphorus contained in excessive levels in the environment is a problem, especially as a source of water pollution. Phosphorus in water is usually present in the form of phosphate compounds $\left(\mathrm{PO}_{4}\right)^{-3}$. Industrial or agricultural waste disposal is the main sourced of phosphate that enters water bodies. Increased phosphate content in the water will trigger algal growth or commonly referred to as eutrophication. Eutrophication has several negative impacts; (1) the proliferation of bloom-forming species that could be toxic or inedible; (2) decreasing of water quality (e.g., color, transparency, odor, taste and water treatment problems); (3) water plants die

\footnotetext{
*Corresponding author.

E-Mail: enyyulianti@kim.uin-malang.ac.id
}

causing propagation of bacterial decomposers; (4) bacteria consume more oxygen causing its shortage in a water body, and thus, kills the fish; (5) loss of biodiversity; and (6) decrease of the esthetic and recreational value of the water body. ${ }^{1}$

There are generally two methods that can be used to reduce dissolved phosphate in the water, chemical methods, and biological methods. The chemical deposition is a method that is often used. Chemical deposition methods cause dissolved phosphate to precipitate from the solution, and then the phosphate deposits can be separated. These results can be obtained if there is an addition of a material called a coagulant. The jar test can be used to determine the chemical combinations and coagulant dosages required for proper coagulation processes. Then, the 
residual phosphate can be analyzed using a UV-Vis spectrophotometer with a heterophosphomolybdate standard solution.

The coagulation process is based on the mechanism of colloidal destabilization by coagulant substances. ${ }^{2}$ Some chemicals that are often used as coagulants, for example, aluminum sulfate and ferric chloride. Previous research has been shown that some chemicals used as coagulants for water purification can cause serious health hazards if an error occurs in the process. The reports that indicate high levels of aluminum in the brain were risk factors for Alzheimer's disease. ${ }^{1}$

Moringa oleifera or Moringa plants have been widely studied as natural absorbents to remove pollutants that are dissolved in water. ${ }^{3}$ Several studies about the characterization of Moringa seed extract showed that Moringa seed extract has a high protein content, which acts as an electrical cationic in polluted water. Moringa seeds extract the highest protein content compared to carbohydrates and fats, 3348, 909 and 800 ppm, respectively. ${ }^{10}$

The extraction of Moringa seeds with the addition of $\mathrm{NaCl}$ in the process was known can reduce the level of turbidity in water significantly ${ }^{4}$. Extraction using $\mathrm{NaCl}$ was used to increase the solubility of protein found in Moringa seeds that function as coagulants. Some proteins are less soluble in water but can dissolve in saline solutions. ${ }^{9}$

The technology of using Moringa seeds as a coagulant has several advantages: the process of extracting Moringa seeds can be done simply, Moringa seed extract was a natural product that was safe for health and not poisonous, Moringa seeds were easily obtained in various regions in Indonesia. ${ }^{3}$ The aim of this study to determine the effectiveness of phosphate coagulation using $\mathrm{NaCl}$ extract from Moringa seeds, and characterization using Fourier transform infrared (FTIR) spectrometer.

\section{Methods}

The study was conducted at the UIN Maulana Malik Ibrahim Malang Chemistry Laboratory.

\section{Material}

The materials used in this study were Moringa seeds, $\mathrm{HCl} 37 \%, \mathrm{NaCl}$ pa, $\mathrm{H}_{2} \mathrm{SO}_{4}$ $96 \%, \mathrm{H}_{2} \mathrm{SO}_{4} 0.1 \mathrm{~N}, \mathrm{NaOH} 0.1 \mathrm{~N}$, distilled water, ammonium molybdate, stannous chloride solution, PP indicator, and potassium dihydrogen phosphate anhydrous. The tools used in this study were glassware, analytical balance, porcelain cup, jar, oven, desiccator, mortar, freezer, hot plate, UV-Vis spectrophotometer (Varian, Cary 50 Bio UVVIS Spectrophotometer), spatula, magnetic stirrer, stirrer bar, Barnstead shaker, $\mathrm{pH}-$ meter, centrifuge, aluminum foil, and Fourier transform infrared (FTIR) spectrometer (Varian, Fts 1000 Spectrometer).

\section{Procedure}

Preparation of Moringa oleifera seeds extraction with $\mathrm{NaCl}$ solutions

The old Moringa seeds were taken and then peeled the outer skin to get the white Moringa seeds. The Moringa seeds were mashed, and their water content measured using the gravimetric method. ${ }^{5}$ One gram of Moringa seed powder was extracted with $100 \mathrm{~mL} \mathrm{NaCl}$ $1 \mathrm{M}$ and stirred using a magnetic stirrer for 15 minutes. The crude extract was filtered to obtain Moringa seed extract, which was tested as a coagulant agent.

Determination of the optimum dose of Moringa seeds extract as a phosphate coagulant

The method followed the research of Okuda et al. ${ }^{6}$ Beaker glasses contained 100 $\mathrm{mL}$ of phosphate solution sample were prepared. The Moringa extract coagulants with concentration variation from $0 \mathrm{~mL} / \mathrm{L}, 10$ $\mathrm{mL} / \mathrm{L}, 20 \mathrm{~mL} / \mathrm{L}, 40 \mathrm{~mL} / \mathrm{L}, 80 \mathrm{~mL} / \mathrm{L}, 160$ $\mathrm{mL} / \mathrm{L}$ and $320 \mathrm{~mL} / \mathrm{L}$ were stirred in beaker glasses contained $100 \mathrm{ml}$ of phospate solution using a $150 \mathrm{rpm}$ shaker for 2 minutes, then the stirring speed was reduce to $45 \mathrm{rpm}$ for 30 minutes. Samples were allowed to settle for 1 hour. The filtrate was taken by pipette as much as $2 \mathrm{~mL}$ for phosphate analysis using an UVVis spectrophotometer. 
Determination of optimum deposition time of Moringa oleifera seeds extract as a phosphate coagulant

$100 \mathrm{~mL}$ phosphate solution was added with the Moringa seed extract sample. The optimum concentration of the extract solution was chosen in this procedure. The extract was then added by stirring at $150 \mathrm{rpm}$ for 2 minutes. Furthermore, it was reduced to 45 rpm for 30 minutes. $^{7}$ The solution was allowed to settle with time variations of 5,15 , 30, 60, 90, and 120 minutes. ${ }^{6}$ Each of the filtrates was taken by a pipette as much as 2 $\mathrm{mL}$ for phosphate analysis using a UV-Vis spectrophotometer.

Determination the effect of $\mathrm{pH}$ variations on the Moringa oleifera seeds extract as a phosphate coagulant

The coagulation measurement of the sample was carried out with $\mathrm{pH}$ variations of $3,4,5,6,7$, and $8 . \mathrm{H}_{2} \mathrm{SO}_{4}(0.1 \mathrm{~N})$ or $\mathrm{NaOH}$ $(0.1 \mathrm{~N})$ to achieve the corresponding $\mathrm{pH}$. The optimum dose of the Moringa oleifera seed extract was added to each of the samples then placed in the shaker slot. The samples were stirring at $150 \mathrm{rpm}$ for 2 minutes as a fast stirring and slow stirring at a speed of $45 \mathrm{rpm}$ for 30 minutes. ${ }^{9}$ The solutions were allowed to settle until the optimum precipitation product was reached. Each of the filtrates was taken and piped as much as $2 \mathrm{~mL}$ for phosphate analysis using a UV-Vis spectrophotometer.

\section{Determination of phosphate standard curves}

$2 \mathrm{~mL}$ phosphate standard solutions with variations of $0,2,4,6,8,10,20$, and $30 \mathrm{ppm}$ were prepared. The solution was added to 50 $\mathrm{mL}$ distilled water, $2 \mathrm{~mL}$ ammonium molybdate reagent, and five drops stano chloride solution. The solution was shaken and allowed to stand for optimum stability. Then the absorbance was measured at the maximum wavelength, and a curve was made between the absorbance value and the phosphate concentration.

\section{Characterization using FTIR}

Functional group analysis using FTIR was performed on the Moringa seeds extract samples before and after treatment with phosphate solution. Moringa seeds extract solution was centrifuged at $2500 \mathrm{rpm}$ for 15 minutes, the supernatant was discarded and the pellets dried. The sample $(2 \mathrm{mg})$ was carefully mashed with $100 \mathrm{mg} \mathrm{KBr}$. The sample was then pressed, so it becomes a pellet with a pressure of 80 torrs and analyzed using an FTIR with a wavenumber of 4000$400 \mathrm{~cm}^{-1}$.

\section{Data analysis}

The obtained data were tested using the ANOVA test. This test was conducted to see the significant effect of the Moringa seeds extract concentration, deposition time, and $\mathrm{pH}$ variation on the reduction of phosphate concentration.

\section{Result and Discussion}

\section{Moringa oleifera Seeds Extraction with NaCl solutions}

The water content of Moringa seeds in this study was $7.361 \%$. Samples that have a moisture content below $10 \%$ can avoid rapid fungus growth so they can be stored for a long period of time. ${ }^{8}$ The Moringa seed powder was extracted with $\mathrm{NaCl}(1 \mathrm{M})$ solution. To investigate the effectiveness of Moringa seeds extract as a phosphate coagulant, an experiment was conducted by a jar test with dose variation, deposition time, and $\mathrm{pH}$ variation. The phosphate residue analyzed by phosphate standard solution curves using a UV-Vis spectrophotometer at $688,9 \mathrm{~nm}$ wavelength, which is the maximum wavelength absorbance of heterophosphomolybdate complex compounds (Figure 2).

\section{Determination of Optimum Condition of Moringa oleifera Seeds Extract as A Phosphate Coagulant}

Determination of optimum dose of Moringa seeds extract as a phosphate coagulant

The optimum dose of Moringa seeds extracts as a phosphate coagulant was 80 
$\mathrm{ml} / \mathrm{L}$. The initial phosphate concentration decreased from $17 \mathrm{ppm}$ to $13.58 \mathrm{ppm}$, or a phosphate reduction rate was $20.659 \%$, as shown in Figure 2. The results of the data analysis showed $F_{\text {count }}>F_{\text {table, }}$ which means that the variation of the coagulant dosage of the extract had a very significant effect on the decrease phosphate solution sample after coagulation.

In this study, the dose of extract in $10 \mathrm{ml} / \mathrm{L}$ until $80 \mathrm{ml} / \mathrm{L}$ showed a significant decrease in phosphate concentration. Coagulation is a destabilizing process of the particle by the addition of the Moringa seeds extract coagulant. Moringa seeds proteins in the extract have a different charge with phosphate. Interaction between cationic polyelectrolytes $\left(\mathrm{NH}_{3}{ }^{+}\right)$of protein with phosphate particles $\left(\mathrm{H}_{2} \mathrm{PO}_{4}^{-}\right)$, which eventually forms a bridge between particle loads and forms a large aggregate (flock) and precipitated. ${ }^{14}$

However, at a higher extract concentration, there is a decrease in the coagulation activity of the extract. This is possible because the addition of excessive coagulant can cause repulsion between the same charge from the coagulant protein. ${ }^{15}$ The excessive cationic polyelectrolytes can cause colloidal deflocculation or restabilization. ${ }^{16}$

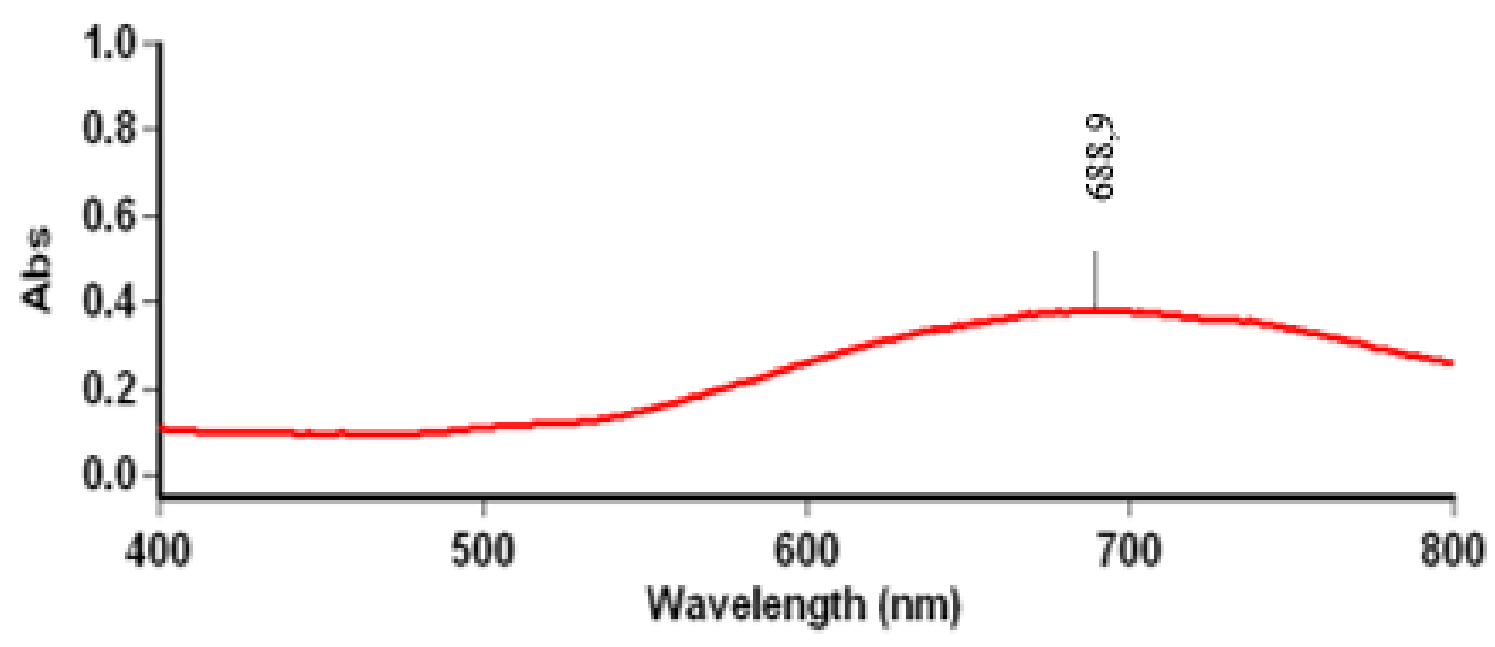

Figure 1. The spectra of heterophosphomolybdate complex compounds

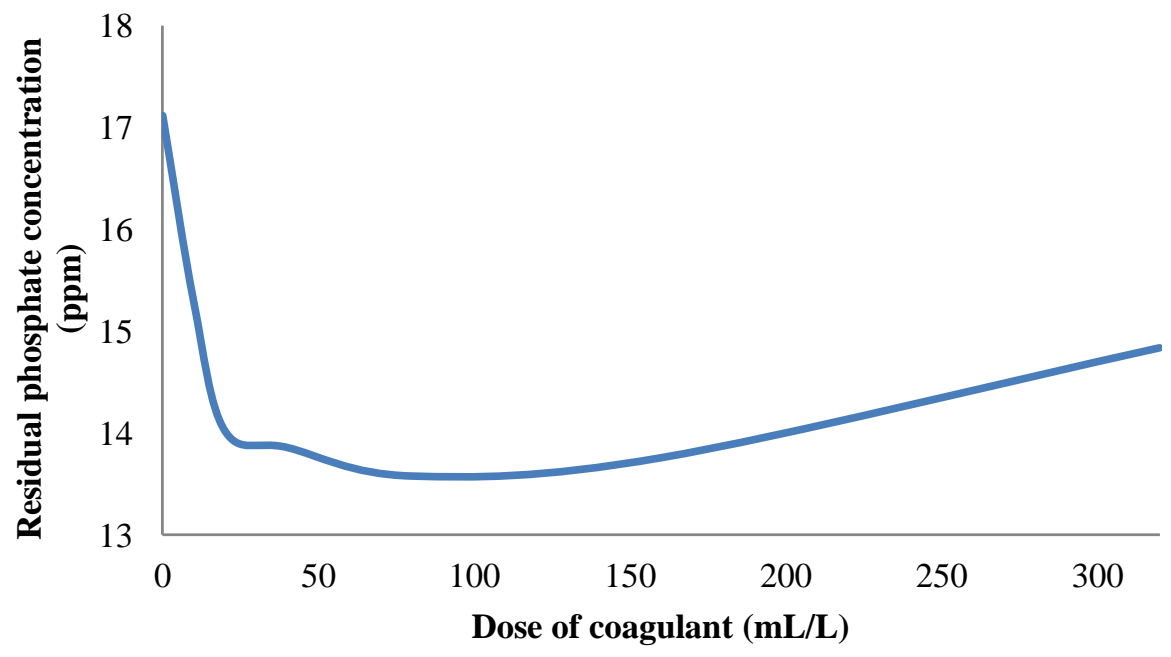

Figure 2. Residual phosphate concentrations at various doses of coagulant 
Determination of optimum deposition time of Moringa seeds extract as a phosphate coagulant

From Figure 3, the optimum deposition time of extract as a phosphate coagulant at 30 minutes. The deposition time is the time needed to precipitate the flocks formed in coagulation. The percentage of decreased phosphate concentration was $31,66 \%$, which reduced $17 \mathrm{ppm}$ to $11,697 \mathrm{ppm}$.

The data showed an increased phosphate concentration again after the optimum deposition time. This occurs because the interaction between coagulant and phosphate influenced by van der Waals force, which is the weakest force. ${ }^{17}$ This force has only small energy, which is about 0.4 to $40 \mathrm{~kJ} / \mathrm{mol}$, which is not enough to produce a covalent bond and it causes released the bond between coagulant and phosphate. ${ }^{14}$
Determination of optimum pH of Moringa seeds extract as a phosphate coagulant

The lowest residual phosphate concentration by coagulant at an optimum dose and optimum deposition time was indicated at $\mathrm{pH} 8$ (Figure 4). The decreased concentration of dissolved phosphate was 17 $\mathrm{ppm}$ to $9.6 \mathrm{ppm}$. The results of data analysis using one-way ANOVA shown that $F_{\text {count }}>$

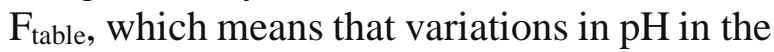
coagulation process have a significant effect on decreasing the phosphate solution sample after being coagulated. The coagulation activity of the extract was highest in alkaline conditions. Under alkaline conditions, the amino acid ions from protein coagulant will form cationic compounds $\left(\mathrm{NH}_{3}^{+}\right)$, while phosphate form anionic compounds $\left(\mathrm{H}_{2} \mathrm{PO}_{4}{ }^{-}\right)$ resulting in van der Waals pulling forces between amino acid cationic polyelectrolytes and phosphate anionic polyelectrolytes. ${ }^{11}$

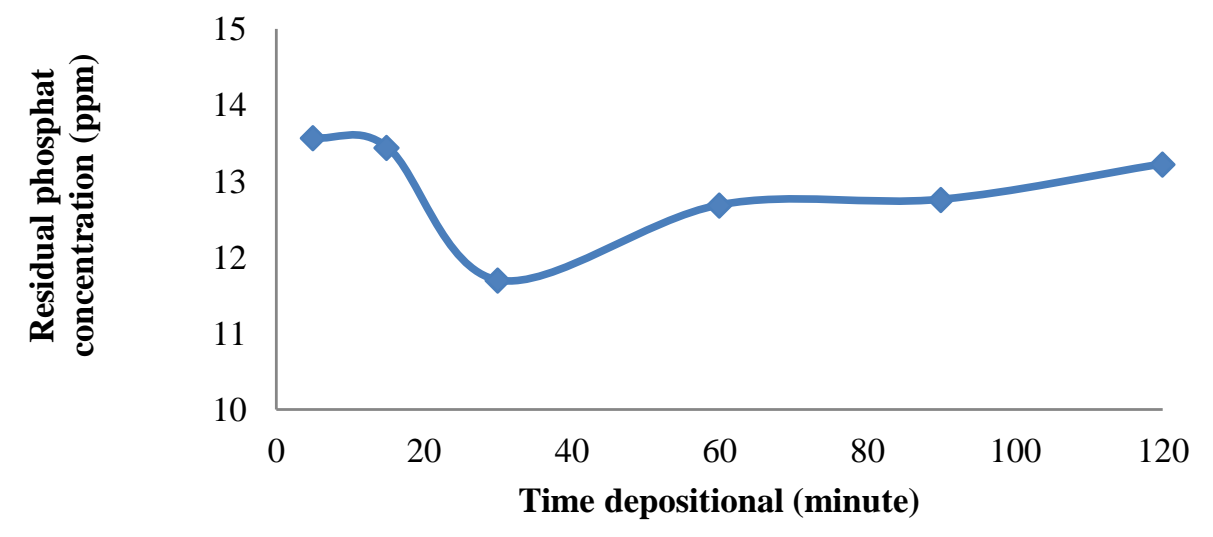

Figure 3. Residual phosphate concentrations at variations in depositional time

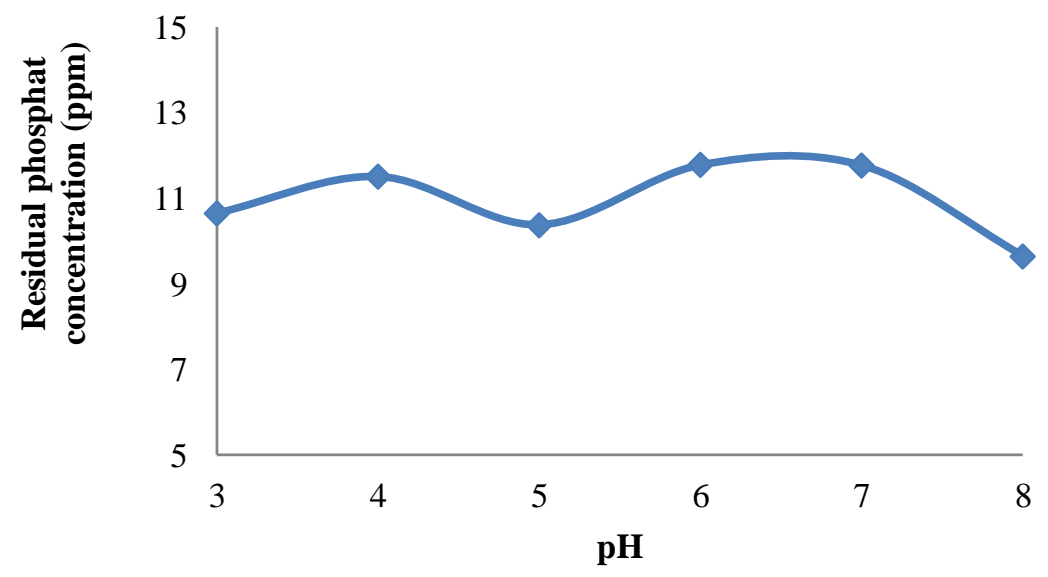

Figure 4. Residual phosphate concentrations at various $\mathrm{pH}$ 
Table 1. FTIR spectrum and functional groups of Moringa seeds extract before and after coagulation with a phosphate solution

\begin{tabular}{|c|c|c|c|}
\hline \multirow{2}{*}{ No } & \multicolumn{2}{|r|}{ Peak values } & \multirow{2}{*}{ Functional group ${ }^{18}$} \\
\hline & Coagulant & Coagulant + phosphate & \\
\hline 1 & 3441,4 & 3427,5 & $\begin{array}{l}\mathrm{N}-\mathrm{H} \text { in Amides, alcohols, } \\
\text { and amines }\end{array}$ \\
\hline 2 & 2925,4 & 2926,1 & \multirow{2}{*}{$\begin{array}{l}\mathrm{O}-\mathrm{CH}_{3} \\
\mathrm{C}-\mathrm{H} \text { in Aldehydes and } \\
\text { acids }\end{array}$} \\
\hline 3 & 2854,6 & 2855,3 & \\
\hline 4 & 1746,3 & 1745,5 & $\mathrm{C}=\mathrm{O}$ in carboxylic acid \\
\hline 5 & 1655,8 & 1654,6 & $\mathrm{C}=\mathrm{O}$ in carboxylic acid \\
\hline 6 & 1543,7 & 1543,1 & $\mathrm{~N}-\mathrm{H}$ \\
\hline 7 & & 1385,0 & $\mathrm{CH}_{2}$ \\
\hline 8 & 1237,3 & 1237,2 & $\mathrm{O}-\mathrm{H}$ \\
\hline 9 & & 1064,2 & $\mathrm{P}-\mathrm{O}$ \\
\hline 10 & & 799,8 & $\mathrm{C}-\mathrm{H}$ \\
\hline 11 & & 668,8 & $\mathrm{P}-\mathrm{N}-\mathrm{C}$ \\
\hline 12 & 574,8 & 571,7 & $\mathrm{~N}=\mathrm{C}=\mathrm{S}$ \\
\hline
\end{tabular}

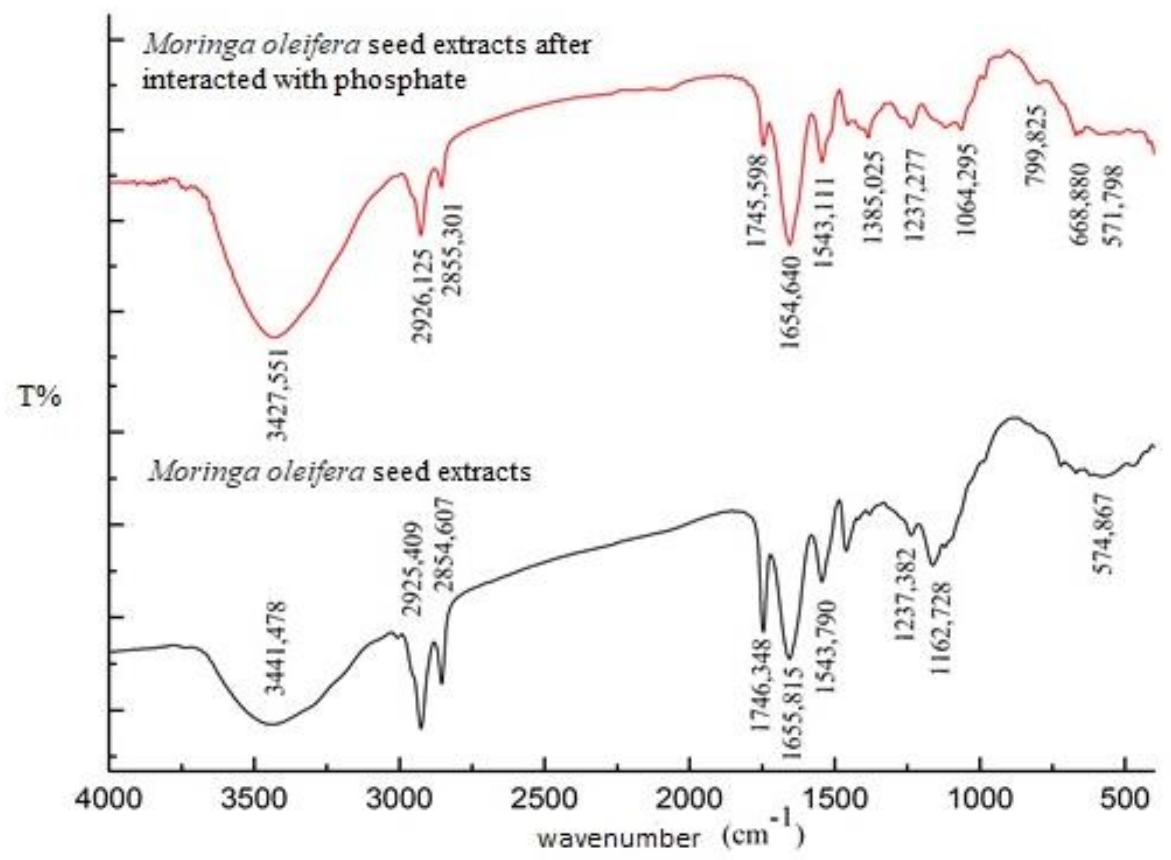

Figure 5. Comparison of spectra of Moringa seeds extract before and after interacting with phosphate

\section{FTIR Characterization}

Characterization of Moringa oleifera seeds extract using FTIR aims to obtain information on the existence of functional groups from a molecule that has a unique vibrational region. The spectra of Moringa seed extract before and after coagulation with phosphate solution are shown in Figure 5. 
The spectra showed the typical bands of the protein functional group (Table 1). The peak at $3441 \mathrm{~cm}^{-1}$ and $3427 \mathrm{~cm}^{-1}$ representing amines, alcohols, and amides indicated $\mathrm{N}-\mathrm{H}$ stretching. The band at $2926 \mathrm{~cm}^{-1}$ and 2925 $\mathrm{cm}^{-1}$ assigned for $\mathrm{O}-\mathrm{CH}_{3}$ stretching. The peak at $2854 \mathrm{~cm}^{-1}$ represents in aldehydes and acids. The band at $1746 \mathrm{~cm}^{-1}$ until $1654 \mathrm{~cm}^{-1}$ assigned for $\mathrm{C}=\mathrm{O}$ stretch in a carboxylic acid. The peak at $1543 \mathrm{~cm}^{-1}$ present in $\mathrm{N}-\mathrm{H}$ stretching, that presence of amides.

Other parameters that indicate the interaction between coagulant and phosphate are the emergence of buckling vibrations at $1064.2 \mathrm{~cm}^{-1}$ representing of $\mathrm{H}_{2} \mathrm{PO}_{4}$, at 799.8 $\mathrm{cm}^{-1}$ assigned for $\mathrm{C}-\mathrm{H}$ stretching and at 668,8 $\mathrm{cm}^{-1}$ assigned for P-N-C stretching. ${ }^{18}$ These bands were caused by an active group in Moringa seeds that have been interacted with a phosphate compound.

\section{Conclusion}

The optimum dose of coagulant was 80 $\mathrm{mL} / \mathrm{L}$ with an initial phosphate concentration from $17 \mathrm{ppm}$ to $13.58 \mathrm{ppm}$. The optimum deposition time was 30 minutes, with a decrease to $11,697 \mathrm{ppm}$, and the optimum $\mathrm{pH}$ was shown to be $\mathrm{pH} 8$, with a decrease in phosphate reaching $9.6 \mathrm{ppm}$. The results of the spectra of Moringa oleifera seeds extract after interacted with phosphate showed several stretching bands that were estimated from a functional group of proteins that acted as coagulants.

Suggestions for further research are Moringa seeds, which have protein as coagulants also have fat content. The fats can interfere with the process of protein extraction by $\mathrm{NaCl}$, so the fat removal process needs to be done to increase the effectiveness of extract as a phosphate coagulant.

\section{Acknowledgment}

We would like to thanks the Faculty of Science and Technology of the State Islamic University of Maulana Malik Ibrahim Malang, who helped materially in this study through Student Competitive Research (PKM).

\section{References}

1. Panasiuk, O. Phosphorus removal and recovery from wastewater using magnetite. 2010.

2. Bunce, J. T., Ndam, E., Ofiteru, I. D., Moore, A., \& Graham, D. W. A review of phosphorus removal technologies and their applicability to small-scale domestic wastewater treatment systems. Front. Environ. Sci.. 2018;6(8).

3. Amagloh, F. K. \& Benang, A. Effectiveness of Moringa oleifera seed as coagulant for water purification. 2009.

4. Sánchez-Martín, J., Beltrán-Heredia, J. \& Peres, J. Improvement of the flocculation process in water treatment by using Moringa oleifera seeds extract. Braz. J. Chem. Eng..2012; 29(3): 495-502

5. Aslamiah, S. S., Yulianti, E. \& Jannah, A. Aktivitas koagulasi Ekstrak Biji Kelor (Moringa oleifera L.) dalam Larutan $\mathrm{NaCl}$ terhadap Limbah Cair IPAL PT. Sier Pier Pasuruan. ALCHEMY.2013; 2(3):178183

6. Okuda, T., Baes, A. U., Nishijima, W. \& Okada, M. Isolation and characterization of coagulant extracted from Moringa oleifera seed by salt solution. Water research. 2001; 35(2): 405-410

7. Okuda, T., Baes, A. U., Nishijima, W. \& Okada, M. Improvement of extraction method of coagulation active components from Moringa oleifera seed. Water research. 1999; 33(15): 3373-3378

8. Winarno, F. Kimia Pangan dan Gizi, Jakarta. Jakarta; PT Gramedia Pustaka Utama; 2002.

9. Gultom, O. W., Lestari, S. \& Nopianti, R. Analisis proksimat, protein larut air, dan protein larut garam pada beberapa jenis ikan air tawar Sumatera Selatan. Jurnal FishtecH. 2015; 4(2): 120-127.

10. Rizqi, W., Yulianti, E. \& Jannah, A. Utilization of $\mathrm{NaCl}$ Solution of Moringa Oleifera Seed Extract as Natural Coagulant at Liquid Waste at PT. Cheil Jedang Indonesia-Jombang. ALCHEMY. 2018;4(1):60-66.

11. Khasanah, U. Efektifitas biji kelor (Moringa Oleifera, LAMK) sebagai 
koagulan fosfat dalam limbah cair rumah sakit: Studi kasus di RSU Dr. Saiful Anwar Malang [Skripsi]. Malang: Universitas Islam Negeri Maulana Malik Ibrahim; 2008.

12. Cornel, P. \& Schaum, C. Phosphorus recovery from wastewater: needs, technologies and costs. Water Sci. Technol. 2009;59(6): 1069-1076.

13. Oleszkiewicz, J., Kruk, D., Devlin, T., Lashkarizadeh, M. \& Yuan, Q. Options for improved nutrient removal and recovery from municipal wastewater in the Canadian context. Winn. MN Can: Water Netw; 2015.

14. Pernitsky, D. J. \& Eng, P. Coagulation 101. in Proceedings, Technology Transfer Conference, Universidade de Calgary: Alberta, Canadá; 2003.

15. Hidayat, S. Pemberdayaan Masyarakat Bantaran Sungai Lematang dalam Menurunkan Kekeruhan Air dengan Biji
Kelor (Moringa oleifera Lam.) sebagai Upaya Pengembangan Proses Penjernihan Air [Disertasi]. Program Studi Pendidik. Biol. Univ. Negeri Malang: Malang; 2006.

16. Ostolska I, Wiśniewska M. Application of the zeta potential measurements to explanation of colloidal $\mathrm{Cr} 2 \mathrm{O} 3$ stability mechanism in the presence of the ionic polyamino acids. Colloid and polymer science. 2014 Oct 1;292(10):2453-64.

17. Nouhi S. Structure formation at solid/liquid interfaces: Understanding self-assembly and environmental challenges $[\mathrm{PhD}$ thesis]. Acta Universitatis Upsaliensis; 2018

18. Socrates G. Infrared and Raman characteristic group frequencies: tables and charts. John Wiley \& Sons; 2004 Jun 18. 